\title{
Bernd Renner, Juvénal et les «Nefs des folz»: rhétorique et «translatio studii»
}

\section{Filippo Fassina}

\section{Q OpenEdition}

1 Journals

\section{Edizione digitale}

URL: https://journals.openedition.org/studifrancesi/4618

DOI: $10.4000 /$ studifrancesi.4618

ISSN: 2421-5856

\section{Editore}

Rosenberg \& Sellier

\section{Edizione cartacea}

Data di pubblicazione: 1 avril 2012

Paginazione: 129

ISSN: 0039-2944

\section{Notizia bibliografica digitale}

Filippo Fassina, «Bernd Renner, Juvénal et les «Nefs des folz»: rhétorique et «translatio studii»», Studi Francesi [Online], 166 (I | LVI) | 2012, online dal 30 novembre 2015, consultato il 19 novembre 2021. URL: http://journals.openedition.org/studifrancesi/4618; DOI: https://doi.org/10.4000/studifrancesi. 4618

Questo documento è stato generato automaticamente il 19 novembre 2021.

\section{(c) (1)}

Studi Francesi è distribuita con Licenza Creative Commons Attribuzione - Non commerciale - Non opere derivate 4.0 Internazionale. 


\title{
Bernd Renner, Juvénal et les «Nefs des folz»: rhétorique et «translatio studii»
}

\author{
Filippo Fassina
}

\section{NOTIZIA}

BERND RENNER, Juvénal et les «Nefs des folz»: rhétorique et «translatio studii», «Bibliothèque d'Humanisme et Renaissance», LXXII, 2 (2010), pp. 283-300.

1 Il presente studio prende in esame l'influenza di Giovenale sulla produzione satirica cinquecentesca, in particolare per quanto riguarda la Nef des Folz, una traduzionerielaborazione della Stultifera Navis di Jakob Locher, che a sua volta traduce un modello tedesco di fine Quattrocento. L'A. si concentra particolarmente sul testo latino, del quale offre un'analisi dettagliata sia dal punto di vista contenutistico - sottolineando l'impiego della satira come denuncia sociale dei costumi del tempo-, sia dal punto di vista dei legami con Giovenale stesso, preferito a Orazio per la sua maggiore durezza. Viene quindi offerta una comparatio fra il testo tedesco, l'intermediario latino e due volgarizzamenti francesi, uno a opera di Jean Drouyn (1498) e uno anonimo (1529/1530): di questa translatio studii del genere satirico vengono presentati diversi esempi volti a sottolineare le modalità di imitazione e le influenze dirette di Giovenale sulle rielaborazioni francesi. 